\title{
Vitamin D status and its influence on outcomes following major burn injury and critical illness
}

\author{
Khaled Al-Tarrah ${ }^{1,2^{*}}$ D, Martin Hewison ${ }^{3}$, Naiem Moiemen ${ }^{2+}$ and Janet M. Lord ${ }^{1+}$
}

\begin{abstract}
Vitamin D deficiency is common among the general population. It is also observed in up to $76 \%$ of critically ill patients. Despite the high prevalence of hypovitaminosis D in critical illness, vitamin D is often overlooked by medical staff as the clinical implications and consequences of vitamin D deficiency in acute contexts remain to be fully understood. Vitamin $\mathrm{D}$ has a broad range of pleotropic effects on various processes and systems including the immuneinflammatory response. 1a,25-dihydroxyvitamin $\mathrm{D}\left(1,25(\mathrm{OH})_{2} \mathrm{D}\right)$, has been shown to promote a tolerogenic immune response limiting deleterious inflammatory effects, modulation of the innate immune system, and enhancement of anti-microbial peptides. Vitamin D deficiency is frequently observed in critically ill patients and has been related to extrinsic causes (i.e., limited sunlight exposure), magnitude of injury/illness, or the treatment started by medical doctors including fluid resuscitation. Low levels of vitamin D in critically ill patients have been associated with sepsis, organ failure, and mortality. Despite this, there are subpopulations of critical illness, such as burn patients, where the literature regarding vitamin $\mathrm{D}$ status and its influence on outcomes remain insufficient. Thermal injury results in damage to both burned and non-burned tissues, as well as induces an exaggerated and persistent immune-inflammatory and hypermetabolic response. In this review, we propose potential mechanisms in which burn injury affects the vitamin D status and summarizes current literature investigating the influence of vitamin D status on outcomes. In addition, we reviewed the literature and trials investigating vitamin D supplementation in critically ill patients and discuss the therapeutic potential of vitamin D supplementation in burn and critically ill patients. We also highlight current limitations of studies that have investigated vitamin D status and supplementation in critical illness. Thermal injury influences vitamin D status. More studies investigating vitamin D depletion in burn patients and its influence on prognosis, via standardized methodology, are required to reach definitive conclusions and influence clinical practice.
\end{abstract}

Keywords: Vitamin D, Critical care, Burns, Trauma, Thermal injury, Critically ill

\section{Background}

Vitamin D insufficiency and deficiency is common in the general population [1] and can be present at up to $76 \%$ in critically ill patients [2]. This is concerning as vitamin $\mathrm{D}$ is increasingly recognized for its wide-ranging biological effects, including modulation of bone metabolism and muscle mass, enhancing immune function and cardiovascular effects [3, 4]. Despite these roles, the

\footnotetext{
* Correspondence: kxa455@bham.ac.uk

${ }^{\dagger}$ Equal contributors

${ }^{1}$ Institute of Inflammation and Ageing, Birmingham University Medical

School, Birmingham B15 2TT, UK

${ }^{2}$ Scar Free Foundation Centre for Burns Research, University Hospital

Birmingham Foundation Trust, Birmingham B15 2WB, UK

Full list of author information is available at the end of the article
}

clinical implications of hypovitaminosis D remain partially understood and therefore often overlooked in acute clinical contexts including burns and trauma. The literature investigating vitamin $\mathrm{D}$ deficiency and its consequences in adult burn patients is limited. Following thermal injury, patients are at prone to develop low vitamin D levels, the impact on short and long-term outcomes of which are relatively unknown.

This review aims to discuss current understanding of vitamin D and its role in critically ill patients, the effect of burn injury on vitamin $\mathrm{D}$ status, the influence of vitamin $\mathrm{D}$ levels on outcomes in burn patients, the therapeutic potential of vitamin $\mathrm{D}$, and current knowledge gaps. 


\section{Review}

\section{Overview of vitamin D axis}

Sunlight and nutrition, including dietary supplementation, are the main sources of vitamin D in humans. Solar ultraviolet $\mathrm{B}$ radiation infiltrates the skin converting 7dehydrocholesterol (7-DHC) to pre-vitamin $\mathrm{D}_{3}$ (pre- $\left.\mathrm{D}_{3}\right)$, which is subsequently converted to vitamin $D_{3}$ [4-6]. Vitamin $\mathrm{D}\left(\mathrm{D}_{2}\right.$ and $\left.\mathrm{D}_{3}\right)$ is also found naturally in certain foods (oily fish, mushrooms, egg yolk) and fortified food products, including cereals, cheese, and milk [4,5]. Vitamin $\mathrm{D}$ from the skin and diet is then transported to the liver bound to vitamin D-binding protein (VDBP) and albumin, where it is hydroxylated to 25-hydroxyvitamin $\mathrm{D}(25(\mathrm{OH}) \mathrm{D})$ [4-6]. This is used to determine a patient's vitamin $\mathrm{D}$ status. $25(\mathrm{OH}) \mathrm{D}$ is then metabolized by the enzyme 25-hydroxyvitamin D-1 $\alpha$ hydroxylase (CYP27B1) in the kidneys to the active form of vitamin $\mathrm{D}, 1 \alpha, 25$ dihydroxyvitamin $\mathrm{D}\left(1,25(\mathrm{OH})_{2} \mathrm{D}\right)$ [4-6], which is then transported to various target cells and tissues where it interacts with intracellular vitamin D receptors (VDRs) to exert transcriptional effects. In addition to the kidneys, various extra-renal sites (such as macrophages) are reported to contain CYP27B1 permitting direct metabolism of $25(\mathrm{OH}) \mathrm{D}$ to exert pleotropic effects via autocrine means [7] (Fig. 1).

\section{Overview of vitamin D biological effects}

Classically, vitamin D is associated with musculoskeletal health by maintaining calcium homeostasis and bone mineralization, decreasing the risk of muscle weakness, osteopenia, osteoporosis, and fractures [4, 7]. Vitamin D exerts most of its physiological effects via $1,25(\mathrm{OH})_{2} \mathrm{D}$ which when bound to its cognate nuclear VDR is able to act as a transcription factor in concert with its retinoid $\mathrm{X}$ receptor heterodimer partner [8, 9]. Gene expression analysis of 53 different tissues from over 500 human donors has shown VDR gene expression in more than half of samples including the adipose tissue, adrenal glands, bladder, colon, fibroblasts, kidney, liver, lung, lymphocytes, pituitary glands, and skin [10, 11]. Accordingly, vitamin $\mathrm{D}$ actions are not limited to the skeletal system. The effects of vitamin D on various cell types and tissues are summarized in Table 1.

Of relevance to this review, vitamin $\mathrm{D}$ has a broad range of beneficial effects on the immune system [12]. An association between the adaptive immune system and vitamin D status was initially observed when VDR levels were shown to be enhanced in activated $\mathrm{T}$ and $\mathrm{B}$ cells [13]. In VDR-expressing $\mathrm{T}$ cells, $1,25(\mathrm{OH})_{2} \mathrm{D}$ promotes a tolerogenic immune response by favoring Th2 and Treg cell differentiation over the more inflammatory Th1 and Th17 cells, thereby limiting deleterious inflammatory activity [14-18]. Other immune-modulatory effects of vitamin $\mathrm{D}$ include differential modulation of the

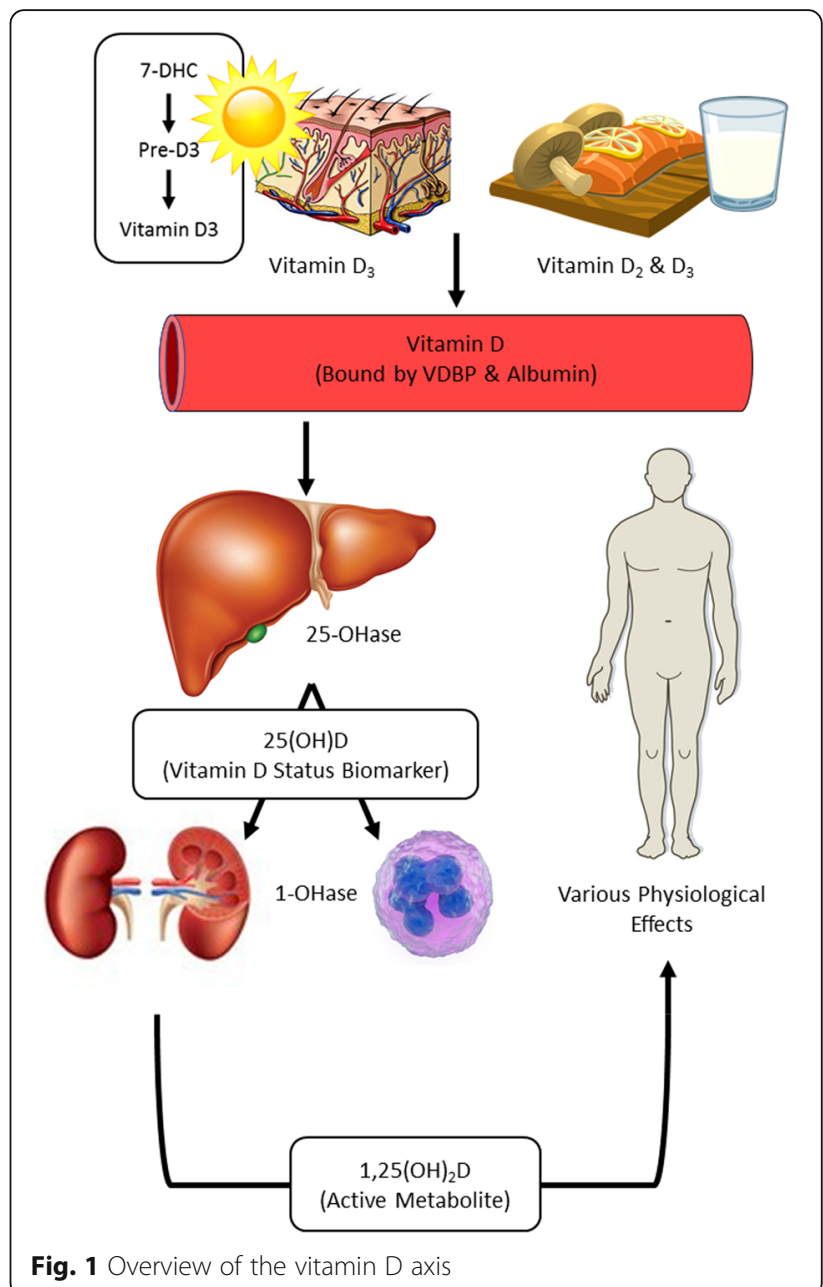

response of the innate immune system (monocytes, macrophages and dendritic cells) [19] with upregulation of anti-microbial peptides such as cathelicidin and $\beta$ defensin 2 from various cells including human keratinocytes and intestinal epithelial cells [20, 21], enhancement of autophagy of intracellular microbes [22], and regulation of antigen-presentation in dendritic cells, monocytes and macrophages to facilitate a non-exaggerated immune response [23]. Crucially, antigen-presenting cells from the innate immune system express the vitamin D-activating enzyme CYP27B1 and are therefore able to metabolize $25(\mathrm{OH}) \mathrm{D}$ in a tissue-specific fashion [24]. This "intracrine" mode of $25(\mathrm{OH}) \mathrm{D}$ metabolism appears to be the principal mechanism by which vitamin $\mathrm{D}$ is able to regulate $\mathrm{T}$ cell function [25] and provides a mechanism by which vitamin D deficiency (low serum 25(OH)D) can influence immune function. The various effects of vitamin D upon the immune response are summarized in Table 1.

DBP and albumin are the main transporters of vitamin D. However, sterol-binding capacity is not the only attribute of DBP and albumin. Multiple roles of DBP have 
Table 1 Effects of vitamin D on various human cell types and tissues

\begin{tabular}{|c|c|c|}
\hline $\begin{array}{l}\text { Target cells/ } \\
\text { tissues }\end{array}$ & Effects of vitamin D & Reference \\
\hline Adipocytes & $\begin{array}{l}\text { - Inhibits intracellular fat accumulation } \\
\text { - Enhances basal lipolysis without cell } \\
\text { toxicity } \\
\text { - Upregulation of } \beta \text {-oxidation-related } \\
\text { genes, lipolytic enzymes, and vitamin } \\
\text { D-responsive genes } \\
\text { - Increased levels of nicotinamide } \\
\text { adenine dinucleotide and sirtulin } \\
1 \text { expression }\end{array}$ & [105] \\
\hline Cardiomyocytes & $\begin{array}{l}\text { - Inhibition of cell proliferation } \\
\text { without apoptosis } \\
\text { - Downregulation of expression of } \\
\text { genes associated with cell cycle } \\
\text { regulation } \\
\text { - Promotes cardiomyotube formation } \\
\text { - Induces cardiac differentiation }\end{array}$ & {$[106,107]$} \\
\hline Hepatocytes & $\begin{array}{l}\text { - Protects against insulin resistance } \\
\text { - Downregulates fibrogenic TGF- } \beta \\
\text { signaling } \\
\text { - Anti-inflammatory effects by } \\
\text { inhibiting monocyte activation } \\
\text { and TNF-a and IL-1 expression }\end{array}$ & [108-110] \\
\hline Myocytes & $\begin{array}{l}\text { - Modulation of calcium homeostasis } \\
\text { and influx } \\
\text { - Induces cellular proliferation and } \\
\text { differentiation } \\
\text { - Protects against insulin resistance } \\
\text { - Stimulation of arachidonic acid } \\
\text { mobilization }\end{array}$ & {$[111,112]$} \\
\hline Nephrocytes & $\begin{array}{l}\text { - Upregulation of cellular metabolic } \\
\text { activity, IL-6, and reactive oxygen } \\
\text { species } \\
\text { - Restoration of transepithelial barrier } \\
\text { function }\end{array}$ & [113] \\
\hline Neurons & $\begin{array}{l}\text { - Neuroactive steroid modulating } \\
\text { spontaneous regular firing, actin } \\
\text { potential duration, and intrinsic } \\
\text { excitability } \\
\text { - Enhances sensitivity to } \\
\text { neurotransmitters and } \\
\text { neurotransmitter receptors } \\
\text { - Upregulation of neuronal } \\
\text { growth factors, neurotrophin 3, } \\
\text { and glial cell line-derived } \\
\text { neurotrophic factor }\end{array}$ & {$[114,115]$} \\
\hline T cells & $\begin{array}{l}\text { - Inhibits Th1/Th17 chemokine/ } \\
\text { cytokine secretion (CXCL-10, IFN- } \gamma \text {, } \\
\text { TNF- } \alpha \text {, and IL-17) } \\
\text { - Enhances Th2 cytokine release } \\
\text { (IL-4 and IL-5) }\end{array}$ & {$[17,116]$} \\
\hline B cells & $\begin{array}{l}\text { - Downregulates the proliferation of } \\
\text { memory B cells } \\
\text { - Inhibits plasma cell differentiation } \\
\text { - Reduces Ig production }\end{array}$ & {$[117]$} \\
\hline $\begin{array}{l}\text { Antigen- } \\
\text { presenting cells }\end{array}$ & $\begin{array}{l}\text { - Inhibits the expression of class II } \\
\text { MHC molecules (HLA-DR) } \\
\text { - Inhibition of co-stimulating molecule } \\
\text { expression (CD80, CD83, and CD86) } \\
\text { - Augments chemotaxis and phagocytosis } \\
\text { of monocytes } \\
\text { - Downregulates the maturation of } \\
\text { dendritic cells }\end{array}$ & [118-121] \\
\hline
\end{tabular}

Table 1 Effects of vitamin D on various human cell types and tissues (Continued)

\begin{tabular}{|c|c|c|}
\hline $\begin{array}{l}\text { Target cells/ } \\
\text { tissues }\end{array}$ & Effects of vitamin D & Reference \\
\hline & $\begin{array}{l}\text { - Induces tolerogenic dendritic } \\
\text { cells capable of inducing Treg cells } \\
\text { - Inhibits IL-12 p70 release } \\
\text { - Decreases macrophage- } \\
\text { stimulated pro-inflammatory } \\
\text { cytokine production (IL-1, IL-1 } \beta \text {, } \\
\text { IL-6, IL-8, MCP-1, and RANTES) }\end{array}$ & \\
\hline NK cells & $\begin{array}{l}\text { - Inhibition of NK cell development } \\
\text { and differentiation } \\
\text { - Reduced INF- } \gamma \text { and cytotoxicity }\end{array}$ & [122] \\
\hline
\end{tabular}

TGF- $\beta$ Transforming growth factor- $\beta$, TNF- $\alpha$ Tumor necrosis factor, IL Interleukin, IFN- $\gamma$ Interferon- $\gamma$, MCP-1 Monocyte chemotactic protein 1, NK Natural killer

been described including actin scavenging, binding of fatty acids and endotoxins, modulation of immune and innate immune responses, and influence on bone metabolism via DBP-macrophage activating factor [26]. Albumin has been reported to exert antioxidant, immunemodulatory, and anti-inflammatory effects, as well as antibiotic transportation and endothelial stabilization [27, 28].

\section{Vitamin D in critically ill and trauma patients}

Considering the pleotropic effects of vitamin D, its role in the severely ill has been a subject of growing interest. Thousands of patients are admitted to intensive care units (ICUs) each year [29], and up to $77 \%$ of critically ill patients have vitamin D deficiency [2, 30-33]. Alizadeh et al. reported that $74 \%$ of critically ill surgical patients exhibited vitamin D deficiency [34]. Similarly, Dickerson et al. reported that $76 \%$ of critically ill patients following traumatic injury were vitamin $\mathrm{D}$ deficient or severely deficient [2]. In such contexts, it is important to recognize patient demographic factors that may be associated with vitamin $\mathrm{D}$ deficiency including age, ethnic group (skin pigmentation), obesity, medical history (such as malabsorption pathologies and liver/renal disease), season, latitude, and time of day [4]. However, it is also vital to comprehend that vitamin D deficiency may itself be a consequence of illness.

Low serum 25(OH)D levels has shown a significant association with the magnitude of the critical illness and systemic inflammatory response syndrome (SIRS) [33, 35, 36]. The well-documented immunomodulatory effects of $1,25(\mathrm{OH})_{2} \mathrm{D}$ suggest that vitamin $\mathrm{D}$ deficiency may be a causative factor for critical illness and resulting morbidity and mortality. The observed vitamin $\mathrm{D}$ deficiency in critically ill and trauma patients may be due to diminished epidermal vitamin $\mathrm{D}$ production secondary to limited sunlight exposure and malnutrition, as well as enhanced conversion of $25(\mathrm{OH}) \mathrm{D}$ to active $1,25(\mathrm{OH})_{2} \mathrm{D}$ to meet increased tissue demand, notably to promote $1,25(\mathrm{OH}) 2 \mathrm{D}$-mediated immunoregulatory effects 
[37]. Finally, critical illness, notably in the setting of inflammation, may promote enhanced catabolism of $25(\mathrm{OH}) \mathrm{D}$ and $1,25(\mathrm{OH})_{2} \mathrm{D}$ to downstream metabolites via the enzyme 24-hydroxylase (CYP24A1) [38]. Interpretation of circulating vitamin $\mathrm{D}$ levels in critical illness is further complicated by the fact that critically ill patients usually require major fluid resuscitation resulting in low levels of $25(\mathrm{OH}) \mathrm{D}$ and $1,25(\mathrm{OH})_{2} \mathrm{D}$ secondary to acute fluid shifts and hemodilution [39]. Vitamin D concentration in critically ill patients post-resuscitation may take, at least, a few days to recover [39]. Secondly, VDBP and albumin levels fall, as part of the systemic inflammatory response, reducing plasma levels of $25(\mathrm{OH}) \mathrm{D}$ significantly [40-42]. This appears to be the case in the acute phase of the response to injury. Furthermore, disruption of the vitamin D axis in ICU patients can be attributed to hepatic, parathyroid, and renal dysfunction, as well as reduced end organ resistance [43].

Clinical studies have associated low levels of circulating vitamin D with various poor outcomes in critically ill patients including sepsis [44, 45], organ failure [46, 47], and short- and long-term mortality [30, 44, 46, 48, 49]. Similar findings have also been reported among both critically ill surgical or trauma patients. For example, low vitamin D levels correlated with higher infection rates, length of stay, duration of organ dysfunction, ICU readmission, surgical intensive care treatment costs, and mortality [50-53]. However, such associations are not universal; other observational studies have reported no association between vitamin D deficiency, sepsis, and mortality $[54,55]$, as well as other ICU outcomes such as duration of ventilation and length of stay [56]. Despite this, several meta-analysis studies have concluded that vitamin D deficiency is associated with significantly increased susceptibility to infections and sepsis, as well as greater incidence of mortality in critically ill patients [57-59].

\section{Burn injury pathophysiology and its impact on vitamin D levels}

Critically ill populations are clearly identified to be at risk of vitamin D deficiency, but there are sub-populations where there is insufficient literature on the status of vitamin $\mathrm{D}$ and its influence on outcomes, including patients with thermal injuries. Although studies investigating vitamin D levels in burns patients are scarce, vitamin D levels have been shown to decrease following thermal injury [60, 61]. This may be both as a primary effect of the injury or secondary response to the injury itself and/or the clinical management initiated such as fluid resuscitation and use of pressure garments.

Burn is a severe form of injury associated with a marked pathophysiological immune-inflammatory response. Thermal injury induces a unique "genomic storm" altering $80 \%$ of the leukocyte transcriptome leading to prolonged simultaneous and rapid stimulation of innate (both pro- and anti-inflammatory genes) and suppression of adaptive immune responses [62]. Clinical studies have recently characterized the immune response following burn injury demonstrating prolonged neutrophil dysfunction and release of immature granulocytes lasting up to 28 days [63], reduced numbers and impaired expression of CD14 +/HLA-DR + monocytes persisting up to 30 days [64], and downregulation of NKG2D (a natural cytotoxicity receptor in natural killer cells) ligands resulting in immunosuppression [65]. The presence of concurrent upregulation of granulocyte-macrophage colony-stimulating factor (GM-CSF), interleukin (IL)-10, and other cytokines following injury indicates an overcompensating response by the body [66], which may last for up to 3 years post-burn [67].

Thermal injury is associated with a hypermetabolic response. The metabolic changes in burn injury and other forms of trauma are similar but differ in magnitude and persistence. These changes are characterized as a two-phase response: the "ebb" phase within $48 \mathrm{~h}$ where metabolism, cardiac output, and oxygen consumption are reduced, followed by the "flow" phase at approximately $120 \mathrm{~h}$ post-injury where these parameters increase and plateau [68]. This metabolic response involves peripheral lipolysis and free fatty acid [69] oxidations leading to acute, global, and complex increase in serum FFA levels [70]; browning of subcutaneous white adipose tissue [71]; systemic induction of endoplasmic reticulum (ER) stress and unfolded protein response [72]; and up to a sixfold increase in breakdown rates of skeletal muscle protein [73]. It is estimated that severe burns cause a surge of resting energy expenditure up to $140 \%$ [74], which can be prolonged [67]. This persistent hypercatabolic, hyperinflammatory response leads to wasting of the patient's tissues and organ, ultimately leading to poorer outcomes.

In addition, fluid and proteins are translocated into burned and non-burned tissues leading to hypovolemia, damaging tissues through direct and indirect means [75]. The extent of which is reflected by elevated levels of damage-associated molecular patterns (DAMPs) such as high-mobility group box protein 1 following burn injury $[76,77]$. There is also disruption of local and systemic vascular permeability via the margination of immune cells including neutrophils, macrophages, and lymphocytes, as well as various inflammatory mediators [78]. This ultimately leads to an instant shift of intravascular fluid to the interstitial space. To address this issue and circumvent the consequences of hypo/hypervolemia, multiple formulations have been established throughout burn care history to optimize fluid resuscitation [79].

Severe burn injury thus induces persistent disturbances of multiple immuno-inflammatory and physiological 
responses simultaneously, befitting the designation: persistent inflammation, immunosuppression, and catabolism syndrome, PICS [80]. This includes reduced circulating levels of vitamin D and its carrier proteins, VDBP and albumin [61]. Based on literature concerning non-burn and burn trauma, we propose that this can be explained through a variety of potential mechanisms: First, as previously postulated [37], there may be attempts to maintain immune homeostasis via increased conversion of $25(\mathrm{OH})$ D to active $1,25(\mathrm{OH})_{2} \mathrm{D}$, thereby reducing circulating $25(\mathrm{OH}) \mathrm{D}$ levels. In individuals who are vitamin Dsufficient prior to injury, this effect may have a negligible impact on serum $25(\mathrm{OH}) \mathrm{D}$ status, but for those who are vitamin D-deficient at injury, this effect may lead to exacerbation of low serum 25(OH)D concentrations; second, fluid resuscitation and a compromised vascular integrity results in decreased serum levels of vitamin D and its metabolites secondary to hemodilution and fluid shifts [39]. VDBP and albumin are also affected in the acute response, thereby reducing bound vitamin $\mathrm{D}$ levels and impacting its delivery to target tissues [40-42]. This phenomenon of binding protein extravasation would be temporary as microvascular integrity is re-established $6 \mathrm{~h}$ following thermal injury [81]. Third, VDBP levels are reduced in the acute stage buffering actin's deleterious effects as part of the actin scavenging system [69, 82].

Although unknown, it appears that VDBP levels recover during the acute phase of thermal injury [83], while albumin levels may recover as early as 6 months [84]. Due to this multiplicity of factors, interpretation of
25(OH)D levels and diagnosing vitamin D deficiency in burn patients remain challenging [85].

Vitamin D levels following severe thermal injury can also be reduced secondary to extrinsic causes including prolonged in-hospital stay (including ICU), prolonged immobilization, and lack of supplementation. Although critically ill burn patients receive oral or enteral feed supplements, current regimens have proved ineffective in replenishing vitamin D levels in the acute phase [60]. Furthermore, current long-term burn management regimens involve scar management comprising mainly of sun avoidance and protection, as well as the use of pressure garments. These factors minimize sun exposure, hence reducing $25(\mathrm{OH}) \mathrm{D}$ levels. In addition, both burn scar and adjacent normal skin in burn patients exhibit subnormal conversion levels of 7-DHC to pre- $\mathrm{D}_{3}$ compared to healthy individuals [86]. This further potentiates vitamin D deficiency, resulting in low levels of $25(\mathrm{OH}) \mathrm{D}$ and $1,25(\mathrm{OH}) 2 \mathrm{D}$ for many years, at least seven, following burn injury [87]. The potential causes of hypovitaminosis D following injury are summarized in Fig. 2.

\section{Influence of vitamin D status on outcomes in burn patients}

Low vitamin D levels in patients with minor burns, median TBSA of $5 \%$, have been associated with increased length of hospital stay [88]. Although not statistically significant, the authors also observed higher complication rates in burn patients with low vitamin D including sepsis, pneumonia, cardiovascular complications, and graft loss 
[88]. It is important to note that low vitamin D status in this study cohort most likely represents the population's pre-injury 25(OH)D levels rather than a consequence of the burn. Furthermore, this study has some limitations. Thirty percent of the cohort was admitted to the ICU with relatively minor injuries, which is unusual. No description of patient pre-morbid state or other pathologies were reported which may potentially affect vitamin D status or outcomes in general. In addition, the cohort is comprised mostly of minor partial thickness thermal injuries limiting its application in severe burns. There are no reports investigating the influence vitamin D levels on short-term outcomes of major burn patients.

Low serum levels of vitamin D in major burn patients have shown to persist for at least 1 year [83]. Long-term outcomes assessed include bone mineral density and leg muscle strength. Although not statistically significant, quadriceps muscle strength was lower at month 12 than the month of injury in burn patients with low vitamin D levels [83]. Another long-term consequence of major thermal injury is scarring. A cross-sectional study has reported a strong negative correlation between circulating $25(\mathrm{OH}) \mathrm{D}$ levels at year 1 post-injury and subjective scar measures (modified Vancouver scar scale) [89]. Both studies were limited by small sample sizes. There are no other studies investigating the influence of vitamin $\mathrm{D}$ on long-term outcomes of burned adult patients.

Studies have reported increased incidence of long bone fractures among children with major burns following discharge [90]. This is most likely attributed to reduced bone mineral density and vitamin D levels [87, 91]. Vitamin D supplementation in pediatric burn patients may be beneficial in reducing fracture risk [91].

\section{Therapeutic potential of vitamin D supplementation}

Vitamin $D_{3}$ supplementation may be associated with decreased mortality in the general population [92]. In addition, vitamin D status has been associated with adverse outcomes in the critically ill. Despite this, there are only a few clinical studies that have evaluated vitamin D supplementation in critically ill patients. In 2014, Amrein et al. conducted the largest randomized controlled trial (RCT) to date investigating the influence of a high-dose bolus enteral vitamin D3 supplementation on outcomes of 475 critically ill medical and surgical adult patients with vitamin D deficiency $(\leq 20 \mathrm{ng} / \mathrm{mL})$, the VITdAL-ICU trial [93]. The authors concluded that high-dose vitamin D3 did not reduce hospital length of stay, hospital mortality, or 6-month mortality [93]. However, they observed lower hospital mortality following subgroup analysis of patients with severe vitamin $\mathrm{D}$ deficiency $(\leq 12 \mathrm{ng} / \mathrm{mL})$ at baseline [93]. A systematic review and meta-analysis of 7 RCTs (716 patients) concluded that vitamin D administration was associated with decreased mortality in critically ill patients without serious adverse events [94]. Interestingly, another recent meta-analysis of 6 RCTs (695 patients) reported no improvement on outcomes in critically ill patients supplemented with vitamin D [95]. The difference between these two studies is related to inclusion and exclusion of various trials in the analysis. Other potentially important confounders in both studies are the inclusion of trials investigating cholecalciferol (vitamin D) and calcitriol $\left(1,25(\mathrm{OH})_{2} \mathrm{D}\right)$ using various dosing regimens that were administered through different routes (enteral and intravenous). Furthermore, the VITdAL-ICU trial has a larger cohort than all the other RCTs combined and therefore has major influence in the statistical analysis. These trials are summarized in Table 2.

Rousseau et al. have shown improved muscle recovery and strength in burn patients supplemented with vitamin D and implied that vitamin D supplementation had positive effects on muscle health and may play a role during rehabilitation [83]. This is the only study investigating the therapeutic potential of vitamin $\mathrm{D}$ following thermal injury. This lack of interventional studies could be due to a variety of reasons. First, as detailed earlier in this review, interpretation of vitamin $D$ status has proven difficult owing to fluid shifts and low protein levels occurring in the acute response. It is assumed that binding protein levels return to normal 1 year postinjury, and therefore, "true" vitamin D status can be analyzed and managed [96]. Second, vitamin D deficiency in burn patients is believed to be a long-term issue [96], requiring a lengthy trial intervention. Third, there is still considerable debate about what vitamin D dosing regimen is optimal for supplementation studies as therapeutic benefit in relation to target serum concentrations of vitamin D remains unclear. In a recent metaanalysis of the effects of vitamin D supplementation on acute upper respiratory infection, positive response to vitamin D supplementation was only observed in patients receiving lower dose daily or weekly supplementation rather than monthly high-dose boluses of vitamin D [97].

\section{Current knowledge gaps and limitations to progress}

Clinical trials investigating the effects of vitamin D supplementation on vitamin D status and outcomes in burn and other critically ill patients are scarce. Correction of vitamin $\mathrm{D}$ depletion in burn patients may prove beneficial, and further studies investigating the therapeutic potential of vitamin D should be encouraged.

A major limitation of this type of study is the different techniques used to analyze vitamin $\mathrm{D}$ levels in patients and the specific vitamin D metabolites measured in each instance. Methods used to quantify the most commonly analyzed vitamin D metabolite-25(OH)D-include immunoassay (IA), high-performance chromatography (HPLC) or liquid chromatography tandem-mass 


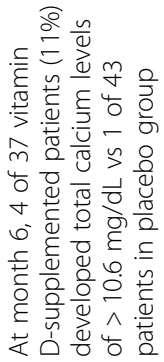

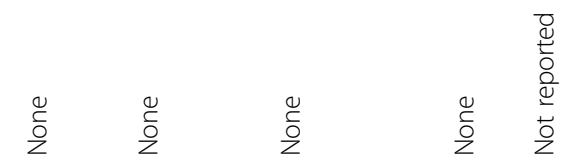

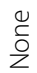

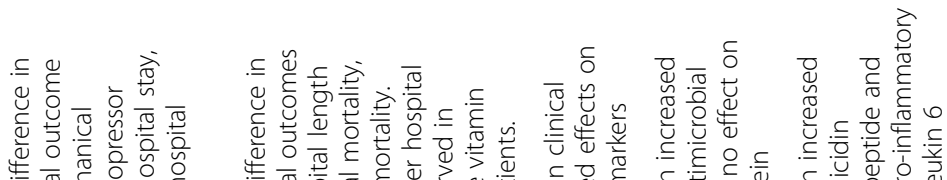

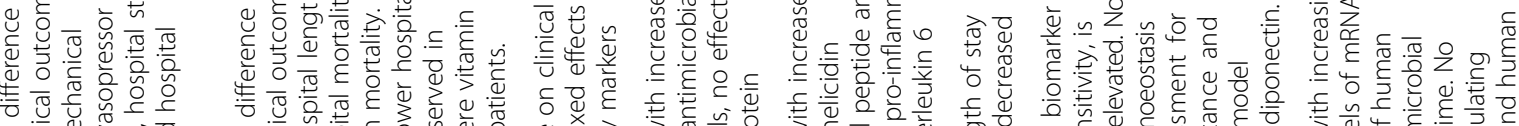

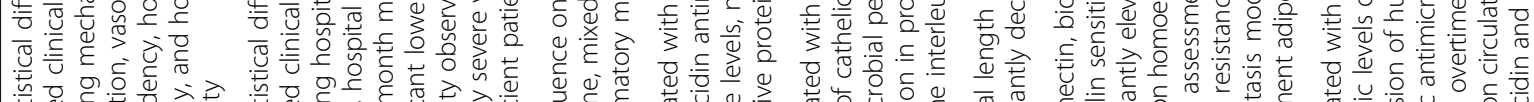

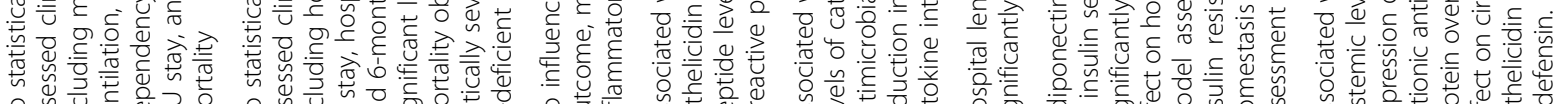
윰.

बতँ

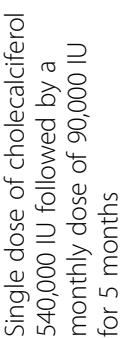

$\sum_{\substack{n+1 \\ n}}^{n}$

$\stackrel{n}{\stackrel{\leftrightarrow}{\gamma}}$

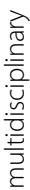

岂 䒕

谣

ज记

旁

훙

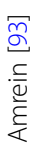

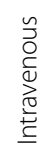

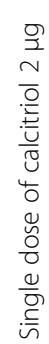

ळ్ㅁㅇ

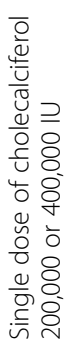

$\sum_{\sum_{1}^{n}}^{n}$

$\sum_{\cup}^{n}$

$\hat{\sigma}$

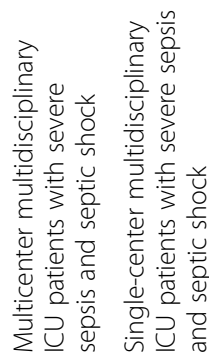

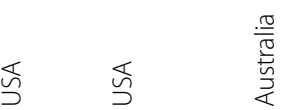

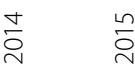

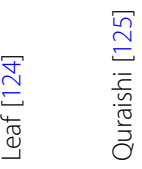

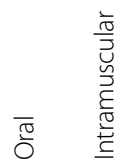

ฮั

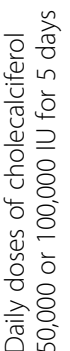

$\frac{\nwarrow}{\uplus}$

ㅇ

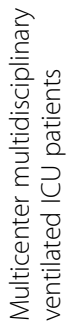

孚

호

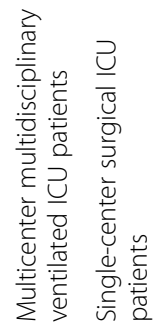

$\stackrel{\sigma}{\beth}$
$\Xi$
$\frac{1}{10}$
I

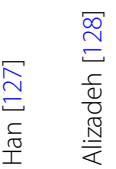

发旁

ำ

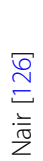


spectrometry (LC-MS/MS). IA measurements are subject to matrix effects, such as hemodilution, and therefore may not be as accurate [98]. Additionally, several IA methods cannot distinguish between the two main forms of vitamin $\mathrm{D}$ (vitamin $\mathrm{D}_{3}$ and vitamin $\mathrm{D}_{2}$ ), and cross-reactivity of vitamin $\mathrm{D}_{3}$ and other vitamin $\mathrm{D}$ metabolites can occur [99]. Vitamin D measurements by IA can also be influenced by VDBP concentration, thereby reducing its reliability [100]. LC-MS/MS involves chromatographic separation and mass transition differences of molecules allowing the differentiation of analytes, thereby increasing selectivity and sensitivity.

Due to differences in the sensitivity of each technique, the data generated may vary in accuracy and reproducibility. Therefore, analyzing and interpreting data obtained using different methodologies in various studies may not be possible. With this in mind, LC-MS/MS has proven to be the only platform offering an accurate, reliable, and reproducible method for quantification of serum $25(\mathrm{OH}) \mathrm{D}$ [99], including studies involving critically ill patients [101]. However, as outlined above, several other vitamin D metabolites, notably active $1,25(\mathrm{OH})_{2} \mathrm{D}$, are likely to play a key role in the physiological activity of vitamin D in critically ill patients. Thus, new analytical strategies are required that incorporate simultaneous measurement of several vitamin D metabolites. LC-MS/MS protocols have been developed allowing accurate simultaneous analysis of various vitamin D metabolites in serum [102]. In addition, new protocols have been developed for the measurement of "free" (VDBP-unbound) 25(OH)D [103]. This bioavailable form of $25(\mathrm{OH}) \mathrm{D}$ is thought to play a crucial role in mediating immunomodulatory responses [104]. In future studies of vitamin D and critical illness, it will be important to incorporate all these new technologies.

\section{Conclusion}

Thermal injury and critical illness influence vitamin D levels. Although data are scarce, vitamin D is most frequently found to be deficient in these patients and may potentially influence short- and long-term outcomes in burn patients and the critically ill. Further studies investigating vitamin $\mathrm{D}$ depletion in burn patients and its influence on prognosis, via standardized methodology such as LC-MS/ MS, are necessary to reach definitive conclusions and influence clinical practice. Although two major RCT trials, VIOLET (NCT03096314) and VITdAL-PICU (NCT02452762), investigating vitamin D supplementation are active, recruited patients will only be given a one-off high dose of vitamin D. More RCTs using "optimal" vitamin D regimens in well-stratified patients are required to determine the utility and risk-benefit ratio of supplementation. These studies are essential to stimulate further clinical and scientific research assessing vitamin D phenomenon in critical care settings, which would be pivotal in determining the need for change in clinical practice.

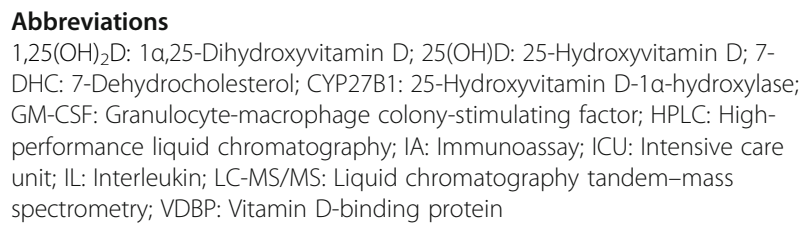

\section{Acknowledgements}

Not applicable

\section{Funding}

KAT is supported by a scholarship from the Kuwaiti Ministry of Health and Civil Service Commission, $\mathrm{MH}$ is supported by the National Institute of Health, NM is supported by the Scar Free Foundation, and JML is supported by the NIHR Surgical Reconstruction and Microbiology Research Centre.

\section{Availability of data and materials}

Not applicable

\section{Authors' contributions}

KAT has written the manuscript. MH, NM, and JML reviewed and wrote the manuscript. All authors read and approved the final manuscript.

Ethics approval and consent to participate

Not applicable

\section{Consent for publication}

Not applicable

\section{Competing interests}

The authors declare that they have no competing interests.

\section{Author details \\ ${ }^{1}$ Institute of Inflammation and Ageing, Birmingham University Medical School, Birmingham B15 2TT, UK. ${ }^{2}$ Scar Free Foundation Centre for Burns Research, University Hospital Birmingham Foundation Trust, Birmingham B15 2WB, UK. ${ }^{3}$ Institute of Metabolism and Systems Research and Centre for Endocrinology Diabetes and Metabolism, The University of Birmingham, Birmingham B15 2TT, UK.}

Received: 29 January 2018 Accepted: 23 March 2018

Published online: 16 April 2018

\section{References}

1. Vitamin D: Increasing supplement use in at-risk groups [https://www.nice. org.uk/guidance/ph56. Accessed 13 May 2017].

2. Dickerson RN, Van Cleve JR, Swanson JM, Maish GO 3rd, Minard G, Croce $M A$, et al. Vitamin D deficiency in critically ill patients with traumatic injuries. Burns \& Trauma. 2016:4:28

3. Bikle DD. Vitamin D metabolism, mechanism of action, and clinical applications. Chem Biol. 2014;21(3):319-29.

4. Holick MF. Vitamin D deficiency. N Engl J Med. 2007;357(3):266-81.

5. Bouillon R, De Groot L, Jameson J: Vitamin D: from photosynthesis, metabolism, and action to clinical applications. Endocrinology 2001: 1010-1028.

6. DeLuca HF. Overview of general physiologic features and functions of vitamin D. Am J Clin Nutr. 2004;80(6 Suppl):1689s-96s.

7. Christakos S, Dhawan P, Verstuyf A, Verlinden L, Carmeliet G. Vitamin D: metabolism, molecular mechanism of action, and pleiotropic effects. Physiol Rev. 2016:96(1):365-408.

8. Carlberg C. The physiology of vitamin D-far more than calcium and bone. Front Physiol. 2014;5:335.

9. Carlberg C. Molecular endocrinology of vitamin D on the epigenome level. Mol Cell Endocrinol. 2017:14-21.

10. The Genotype-Tissue Expression (GTEx) project [https://gtexportal.org/ home/gene/VDR. Accessed 31 March 2017].

11. The Genotype-Tissue Expression (GTEx) project. Nat Genet. 2013;45(6):580-5. 
12. Hewison M. Vitamin D and immune function: an overview. Proc Nutr Soc. 2012;71(1):50-61.

13. Nunn JD, Katz DR, Barker S, Fraher LJ, Hewison M, Hendy GN, et al. Regulation of human tonsillar T-cell proliferation by the active metabolite of vitamin D3. Immunology. 1986;59(4):479-84.

14. Boonstra A, Barrat FJ, Crain C, Heath VL, Savelkoul HF, O'Garra A. 1alpha,25Dihydroxyvitamin $\mathrm{d} 3$ has a direct effect on naive CD4(+) T cells to enhance the development of Th2 cells. J Immunol. 2001;167(9):4974-80.

15. Overbergh L, Decallonne B, Waer M, Rutgeerts O, Valckx D, Casteels KM, et al. 1alpha,25-dihydroxyvitamin D3 induces an autoantigen-specific T-helper 1/T-helper 2 immune shift in NOD mice immunized with GAD65 (p524-543). Diabetes. 2000;49(8):1301-7.

16. O'Kelly J, Hisatake J, Hisatake Y, Bishop J, Norman A, Koeffler HP. Normal myelopoiesis but abnormal $T$ lymphocyte responses in vitamin $D$ receptor knockout mice. J Clin Invest. 2002;109(8):1091-9.

17. Colin EM, Asmawidjaja PS, van Hamburg JP, Mus AM, van Driel M, Hazes JM, et al. 1,25-dihydroxyvitamin D3 modulates Th17 polarization and interleukin22 expression by memory $T$ cells from patients with early rheumatoid arthritis. Arthritis Rheum. 2010;62(1):132-42.

18. Daniel C, Sartory NA, Zahn N, Radeke HH, Stein JM. Immune modulatory treatment of trinitrobenzene sulfonic acid colitis with calcitriol is associated with a change of a T helper (Th) 1/Th17 to a Th2 and regulatory T cell profile. J Pharmacol Exp Ther. 2008;324(1):23-33.

19. Kundu R, Theodoraki A, Haas CT, Zhang Y, Chain B, Kriston-Vizi J, et al. Celltype-specific modulation of innate immune signalling by vitamin $D$ in human mononuclear phagocytes. Immunology. 2017;150(1):55-63.

20. Svensson D, Nebel D, Voss U, Ekblad E, Nilsson BO. Vitamin D-induced up-regulation of human keratinocyte cathelicidin anti-microbial peptide expression involves retinoid X receptor alpha. Cell Tissue Res. 2016; 366(2):353-62

21. Huang FC. The differential effects of 1,25-dihydroxyvitamin D3 on salmonella-induced interleukin-8 and human beta-defensin-2 in intestinal epithelial cells. Clin Exp Immunol. 2016;185(1):98-106.

22. Liu WC, Zheng CM, Lu CL, Lin YF, Shyu JF, Wu CC, et al. Vitamin D and immune function in chronic kidney disease. Clinica Chimica Acta. 2015; 450:135-44.

23. Alhassan Mohammed $H$, Saboor-Yaraghi AA, Mirshafiey A, Vahedi $H$, ShiriShahsavar MR. Mousavi Nasl Khameneh a: immunomodulatory and immunosuppressive roles of 1alpha,25(OH)2D3 in autoimmune diseases. Scand J Immunol. 2017;85(2):95-103.

24. Hewison M. Antibacterial effects of vitamin D. Nat Rev Endocrinol. 2011; 7(6):337-45.

25. Jeffery LE, Wood AM, Qureshi OS, Hou TZ, Gardner D, Briggs Z, et al. Availability of 25-Hydroxyvitamin D3 to APCs controls the balance between regulatory and inflammatory T cell responses. J Immunol. 2012;189(11): 5155-64.

26. Delanghe JR, Speeckaert R, Speeckaert MM. Behind the scenes of vitamin D binding protein: more than vitamin D binding. Best Pract Res Clin Endocrinol Metab. 2015;29(5):773-86.

27. Ferrer R, Mateu X, Maseda E, Yebenes JC, Aldecoa C, De Haro C, et al. Non-oncotic properties of albumin. A multidisciplinary vision about the implications for critically ill patients. Expert Rev Clin Pharmacol. 2018;11(2):125-37.

28. Vincent $J \mathrm{~L}$, De Backer $\mathrm{D}$, Wiedermann CJ: Fluid management in sepsis: the potential beneficial effects of albumin. J Crit Care 2016, 35:161-167.

29. Mullins PM, Goyal M, Pines JM. National growth in intensive care unit admissions from emergency departments in the United States from 2002 to 2009. Acad Emerg Med Off J Soc Acad Emerg Med. 2013;20(5):479-86

30. Amrein K, Zajic P, Schnedl C, Waltensdorfer A, Fruhwald S, Holl A, et al. Vitamin $D$ status and its association with season, hospital and sepsis mortality in critical illness. Crit Care. 2014;18(2):R47.

31. Aygencel G, Turkoglu M, Tuncel AF, Candır BA, Bildacı YD, Pasaoglu H. Is vitamin D insufficiency associated with mortality of critically ill patients? Crit Care Res Prac. 2013;2013

32. Lee $P$, Eisman JA, Center JR. Vitamin D deficiency in critically ill patients. N Engl J Med. 2009;360(18):1912-4.

33. Nair P, Lee P, Reynolds C, Nguyen ND, Myburgh J, Eisman JA, et al. Significant perturbation of vitamin D-parathyroid-calcium axis and adverse clinical outcomes in critically ill patients. Intensive Care Med. 2013;39(2):267-74
34. Alizadeh $N$, Khalili H, Mohammadi M, Abdollahi A. Serum vitamin D levels at admission predict the length of intensive care unit stay but not in-hospital mortality of critically ill surgical patients. J Res Pharma Prac. 2015;4(4):193-8.

35. Hu J, Luo Z, Zhao X, Chen Q, Chen Z, Qin H, et al. Changes in the calciumparathyroid hormone-vitamin $\mathrm{d}$ axis and prognosis for critically ill patients: a prospective observational study. PLoS One. 2013;8(9):e75441.

36. Ghashut RA, Talwar D, Kinsella J, Duncan A, McMillan DC. The effect of the systemic inflammatory response on plasma vitamin $25(\mathrm{OH}) \mathrm{D}$ concentrations adjusted for albumin. PLoS One. 2014;9(3):e92614.

37. Lee $P$, Nair $P$, Eisman JA, Center JR. Vitamin D deficiency in the intensive care unit: an invisible accomplice to morbidity and mortality? Intensive Care Med. 2009;35(12):2028-32.

38. Schrumpf JA, Amatngalim GD, Veldkamp JB, Verhoosel RM, Ninaber DK, Ordonez SR, et al. Proinflammatory cytokines impair vitamin D-induced host defense in cultured airway epithelial cells. Am J Respir Cell Mol Biol. 2017; 56(6):749-61.

39. Krishnan A, Ochola J, Mundy J, Jones M, Kruger P, Duncan E, et al. Acute fluid shifts influence the assessment of serum vitamin D status in critically ill patients. Critical care. 2010;14(6):R216.

40. Reid D, Toole BJ, Knox S, Talwar D, Harten J, O'Reilly DS, et al. The relation between acute changes in the systemic inflammatory response and plasma 25-hydroxyvitamin D concentrations after elective knee arthroplasty. Am J Clin Nutr. 2011;93(5):1006-11.

41. Dahl B, Schiodt FV, Kiaer T, Ott P, Bondesen S, Tygstrup N. Serum Gc-globulin in the early course of multiple trauma. Crit Care Med. 1998;26(2):285-9.

42. Waldron JL, Ashby HL, Cornes MP, Bechervaise J, Razavi C, Thomas OL, et al. Vitamin D: a negative acute phase reactant. J Clin Pathol. 2013;66(7):620-2.

43. Amrein K, Christopher KB, McNally JD. Understanding vitamin D deficiency in intensive care patients. Intensive Care Med. 2015:41(11):1961-4.

44. Moromizato T, Litonjua AA, Braun AB, Gibbons FK, Giovannucci E, Christopher KB. Association of low serum 25-hydroxyvitamin D levels and sepsis in the critically ill. Crit Care Med. 2014;42(1):97-107.

45. Jovanovich AJ, Ginde AA, Holmen J, Jablonski K, Allyn RL, Kendrick J, et al. Vitamin $D$ level and risk of community-acquired pneumonia and sepsis. Nutrients. 2014;6(6):2196-205.

46. Braun AB, Litonjua AA, Moromizato T, Gibbons FK, Giovannucci E, Christopher KB. Association of low serum 25-hydroxyvitamin D levels and acute kidney injury in the critically ill. Crit Care Med. 2012;40(12):3170-9.

47. Thickett DR, Moromizato T, Litonjua AA, Amrein K, Quraishi SA, Lee-Sarwar $K A$, et al. Association between prehospital vitamin D status and incident acute respiratory failure in critically ill patients: a retrospective cohort study. BMJ Open Resp Res. 2015;2(1):e000074.

48. Venkatram S, Chilimuri S, Adrish M, Salako A, Patel M, Diaz-Fuentes G. Vitamin D deficiency is associated with mortality in the medical intensive care unit. Critical care. 2011;15(6):R292.

49. Chen Z, Luo Z, Zhao X, Chen Q, Hu J, Qin H, et al. Association of vitamin D status of septic patients in intensive care units with altered procalcitonin levels and mortality. J Clin Endocrinol Metab. 2015;100(2):516-23.

50. Matthews LR, Ahmed Y, Wilson KL, Griggs DD, Danner OK. Worsening severity of vitamin $D$ deficiency is associated with increased length of stay, surgical intensive care unit cost, and mortality rate in surgical intensive care unit patients. Am J Surg. 2012;204(1):37-43.

51. Flynn L, Zimmerman LH, McNorton K, Dolman M, Tyburski J, Baylor A, et al. Effects of vitamin D deficiency in critically ill surgical patients. Am J Surg. 2012;203(3):379-82. discussion 382

52. Quraishi SA, Bittner EA, Blum L, McCarthy CM, Bhan I, Camargo CA Jr. Prospective study of vitamin D status at initiation of care in critically ill surgical patients and risk of 90-day mortality. Crit Care Med. 2014;42(6): 1365-71.

53. Quraishi SA, McCarthy C, Blum L, Cobb JP, Camargo CA Jr. Plasma 25Hydroxyvitamin D levels at initiation of care and duration of mechanical ventilation in critically ill surgical patients. JPEN J Parenter Enteral Nutr. 2016:40(2):273-8.

54. Ala-Kokko TI, Mutt SJ, Nisula S, Koskenkari J, Liisanantti J, Ohtonen P, et al. Vitamin D deficiency at admission is not associated with 90-day mortality in patients with severe sepsis or septic shock: observational FINNAKI cohort study. Ann Med. 2016;48(1-2):67-75.

55. Ratzinger F, Haslacher $H$, Stadlberger M, Schmidt RLJ, Obermüller M, Schmetterer $\mathrm{KG}$, et al. 25(OH)D and 1,25(OH)D vitamin D fails to predict sepsis and mortality in a prospective cohort study. Sci Rep. 2017;7 
56. Vosoughi N, Kashefi P, Abbasi B, Feizi A, Askari G, Azadbakht L. The relationship between vitamin $D$, clinical outcomes and mortality rate in ICU patients: a prospective observational study. J Res Med Sci. 2016;21:75.

57. Zhang YP, Wan YD, Sun TW, Kan QC, Wang LX. Association between vitamin $D$ deficiency and mortality in critically ill adult patients: a metaanalysis of cohort studies. Critical care. 2014;18(6):684.

58. de Haan K, Groeneveld AB, de Geus HR, Egal M, Struijs A. Vitamin D deficiency as a risk factor for infection, sepsis and mortality in the critically ill: systematic review and meta-analysis. Critical care. 2014;18(6):660.

59. Upala S, Sanguankeo A, Permpalung N. Significant association between vitamin $D$ deficiency and sepsis: a systematic review and meta-analysis. BMC Anesthesiol. 2015;15:84.

60. Rousseau AF, Damas P, Ledoux D, Cavalier E. Effect of cholecalciferol recommended daily allowances on vitamin $D$ status and fibroblast growth factor-23: an observational study in acute burn patients. Burns. 2014;40(5):865-70.

61. Rousseau AF, Damas P, Ledoux D, Lukas P, Carlisi A, Le Goff C et al: Vitamin $D$ status after a high dose of cholecalciferol in healthy and burn subjects. Burns 2015, 41(5):1028-1034.

62. Xiao W, Mindrinos MN, Seok J, Cuschieri J, Cuenca AG, Gao H, et al. A genomic storm in critically injured humans. J Exp Med. 2011;208(13): 2581-90.

63. Hampson P, Dinsdale RJ, Wearn CM, Bamford AL, Bishop JR, Hazeldine J, et al. Neutrophil dysfunction, immature granulocytes, and cell-free DNA are early biomarkers of Sepsis in burn-injured patients: a prospective observational cohort study. Ann Surg. 2016;

64. Jeschke MG, Patsouris D, Stanojcic M, Abdullahi A, Rehou S, Pinto R, et al. Pathophysiologic response to burns in the elderly. EBioMedicine. 2015;2(10):1536-48.

65. Haik J, Nardini G, Goldman N, Galore-Haskel G, Harats M, Zilinsky I, et al. Increased serum NKG2D-ligands and downregulation of NKG2D in peripheral blood NK cells of patients with major burns. Oncotarget. 2016; 7(3):2220-8

66. Finnerty CC, Jeschke MG, Herndon DN, Gamelli R, Gibran N, Klein M, et al. Temporal cytokine profiles in severely burned patients: a comparison of adults and children. Mol Med Mass. 2008;14(9-10):553-60.

67. Jeschke MG, Gauglitz GG, Kulp GA, Finnerty CC, Williams FN, Kraft R, et al. Long-term persistance of the pathophysiologic response to severe burn injury. PLoS One. 2011;6(7):e21245.

68. Wolfe RR. Review: acute versus chronic response to burn injury. Circ Shock 1981;8(1):105-15.

69. Otterbein LR, Cosio C, Graceffa P, Dominguez R. Crystal structures of the vitamin D-binding protein and its complex with actin: structural basis of the actin-scavenger system. Proc Natl Acad Sci U S A. 2002;99(12):8003-8.

70. Qi P, Abdullahi A, Stanojcic M, Patsouris D, Jeschke MG. Lipidomic analysis enables prediction of clinical outcomes in burn patients. Sci Rep. 2016;6:38707.

71. Patsouris D. Burn Induces Browning of the Subcutaneous White Adipose Tissue in Mice and Humans. Cell Rep. 2015;13(8):1538-44.

72. Jeschke MG, Finnerty CC, Herndon DN, Song J, Boehning D, Tompkins RG, et al. Severe injury is associated with insulin resistance, endoplasmic reticulum stress response, and unfolded protein response. Ann Surg. 2012; 255(2):370-8.

73. Chao T, Herndon DN, Porter C, Chondronikola M, Chaidemenou A, Abdelrahman DR, et al. Skeletal muscle protein breakdown remains elevated in pediatric burn survivors up to one-year post-injury. Shock. 2015; 44(5):397-401.

74. Jeschke MG, Chinkes DL, Finnerty CC, Kulp G, Suman OE, Norbury WB, et al. Pathophysiologic response to severe burn injury. Ann Surg. 2008; 248(3):387-401.

75. Cope O, Moore FD. The redistribution of body water and the fluid therapy of the burned patient. Ann Surg. 1947;126(6):1010-45.

76. Lantos J, Foldi V, Roth E, Weber G, Bogar L, Csontos C. Burn trauma induces early HMGB1 release in patients: its correlation with cytokines. Shock. 2010; 33(6):562-7.

77. Qian WJ, Petritis BO, Kaushal A, Finnerty CC, Jeschke MG, Monroe ME, et al Plasma proteome response to severe burn injury revealed by (18)O-labeled "universal" reference-based quantitative proteomics. J Proteome Res. 2010; 9(9):4779-89.

78. Arturson G. Microvascular permeability to macromolecules in thermal injury. Acta Physiol Scand Suppl. 1979;463:111-22.
79. Liu HF, Zhang F, Lineaweaver WC. History and advancement of burn treatments. Ann Plast Surg. 2017;78(2 Suppl 1):S2-s8.

80. Gentile LF, Cuenca AG, Efron PA, Ang D, McKinley BA, Moldawer LL, et al. Persistent inflammation and immunosuppression: a common syndrome and new horizon for surgical intensive care. J Trauma Acute Care Surg. 2012;72(6):1491-501.

81. Vlachou E, Gosling P, Moiemen NS. Microalbuminuria: a marker of endothelial dysfunction in thermal injury. Burns. 2006;32(8):1009-16.

82. Lee WM, Galbraith RM. The extracellular actin-scavenger system and actin toxicity. N Engl J Med. 1992;326(20):1335-41.

83. Rousseau AF, Foidart-Desalle M, Ledoux D, Remy C, Croisier JL, Damas P, et al. Effects of cholecalciferol supplementation and optimized calcium intakes on vitamin D status, muscle strength and bone health: a one-year pilot randomized controlled trial in adults with severe burns. Burns. 2015; 41(2):317-25.

84. Klein GL, Herndon DN, Chen TC, Kulp G, Holick MF. Standard multivitamin supplementation does not improve vitamin D insufficiency after burns. J Bone Miner Metab. 2009;27(4):502-6.

85. Quraishi SA, Camargo CA Jr. Vitamin D in acute stress and critical illness. Curr Opin Clin Nutr Metab Care. 2012;15(6):625-34.

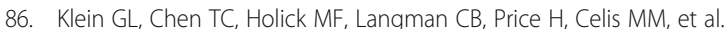
Synthesis of vitamin D in skin after burns. Lancet. 2004;363(9405):291-2.

87. Klein GL, Langman CB, Herndon DN. Vitamin D depletion following burn injury in children: a possible factor in post-burn osteopenia. J Trauma. 2002;52(2):346-50.

88. Blay B, Thomas S, Coffey R, Jones L, Murphy CV. Low vitamin D level on admission for burn injury is associated with increased length of stay. J Burn Care Res. 2017;38(1):e8-e13.

89. Terzi R, Guven M. Bone mineral density after burn injury and its relation to the characteristics of scar tissue. J Burn Care Res. 2016;37(3):e263-7.

90. Mayes T, Gottschlich M, Scanlon J, Warden GD. Four-year review of burns as an etiologic factor in the development of long bone fractures in pediatric patients. J Burn Care Rehabil. 2003;24(5):279-84.

91. Mayes T, Gottschlich MM, Khoury J, Kagan RJ. Investigation of bone health subsequent to vitamin D supplementation in children following burn injury. Nutr Clin Pract. 2015:30(6):830-7.

92. Bjelakovic G, Gluud LL, Nikolova D, Whitfield K, Wetterslev J, Simonetti RG, et al. Vitamin D supplementation for prevention of mortality in adults. Cochrane Data System Rev. 2014;1:Cd007470.

93. Amrein K, Schnedl C, Holl A, Riedl R, Christopher KB, Pachler C, et al. Effect of high-dose vitamin D3 on hospital length of stay in critically ill patients with vitamin D deficiency: the VITdAL-ICU randomized clinical trial. JAMA. 2014;312(15):1520-30

94. Putzu A, Belletti A, Cassina T, Clivio S, Monti G, Zangrillo A, et al. Vitamin D and outcomes in adult critically ill patients. A systematic review and metaanalysis of randomized trials. J Crit Care. 2017;38:109-14.

95. Langlois PL, Szwec C, D'Aragon F, Heyland DK, Manzanares W. Vitamin D supplementation in the critically ill: a systematic review and meta-analysis. Edinburgh: Clinical nutrition; 2017.

96. Klein GL. Should we give vitamin D to severe burns patients? The conundrum. Burns. 2014;40(1):169.

97. Martineau AR, Jolliffe DA, Hooper RL, Greenberg L, Aloia JF, Bergman P, et al. Vitamin $\mathrm{D}$ supplementation to prevent acute respiratory tract infections: systematic review and meta-analysis of individual participant data. BMJ Clin Res. 2017:i6583:356.

98. El-Khoury JM, Reineks EZ, Wang S. Progress of liquid chromatography-mass spectrometry in measurement of vitamin D metabolites and analogues. Clin Biochem. 2011;44(1):66-76.

99. Taylor AE, Keevil B, Huhtaniemi IT. Mass spectrometry and immunoassay: how to measure steroid hormones today and tomorrow. Eur J Endocrinol. 2015;173(2):D1-12

100. Heijboer AC, Blankenstein MA, Kema IP, Buijs MM. Accuracy of 6 routine 25-hydroxyvitamin D assays: influence of vitamin D binding protein concentration. Clin Chem. 2012:58(3):543-8.

101. Rousseau AF, Damas P, Janssens M, Kalin S, Ledoux D, Le Goff C, et al. Critical care and vitamin D status assessment: what about immunoassays and calculated free 25OH-D? Clin Chim Acta. 2014;437:43-7.

102. Jenkinson C, Taylor AE, Hassan-Smith ZK, Adams JS, Stewart PM, Hewison M, et al. High throughput LC-MS/MS method for the simultaneous analysis of multiple vitamin D analytes in serum. J Chromatogr B Anal Technol Biomed Life Sci. 2016;1014:56-63. 
103. Nielson CM, Jones KS, Chun RF, Jacobs JM, Wang Y, Hewison M, et al. Free 25-Hydroxyvitamin D: impact of vitamin D binding protein assays on racial-genotypic associations. J Clin Endocrinol Metab. 2016;101(5):2226-34

104. Chun RF, Lauridsen AL, Suon L, Zella LA, Pike JW, Modlin RL, et al. Vitamin D-binding protein directs monocyte responses to 25-hydroxy- and 1,25-dihydroxyvitamin D. J Clin Endocrinol Metab. 2010;95(7):3368-76.

105. Chang E, Kim Y. Vitamin D decreases adipocyte lipid storage and increases NAD-SIRT1 pathway in 3T3-L1 adipocytes. Nutrition. 2016;32(6):702-8.

106. Kim IM, Norris KC, Artaza JN. Vitamin D and cardiac differentiation. Vitam Horm. 2016;100:299-320

107. Hlaing SM, Garcia LA, Contreras JR, Norris KC, Ferrini MG, Artaza JN. 1,25-vitamin D3 promotes cardiac differentiation through modulation of the WNT signaling pathway. J Mol Endocrinol. 2014;53(3):303-17.

108. Tao S, Yuan Q, Mao L, Chen FL, Ji F, Cui ZH. Vitamin D deficiency causes insulin resistance by provoking oxidative stress in hepatocytes. Oncotarget. 2017;8(40):67605-13.

109. Beilfuss A, Sowa J-P, Sydor S, Beste M, Bechmann LP, Schlattjan M, et al. Vitamin D counteracts fibrogenic TGF- $\beta$ signalling in human hepatic stellate cells both receptor-dependently and independently. Gut. 2015;64(5):791-9.

110. Chen G, Ni Y, Nagata N, Xu L, Ota T. Micronutrient antioxidants and nonalcoholic fatty liver disease. Int J Mol Sci. 2016;17(9):1379.

111. Dirks-Naylor AJ, Lennon-Edwards S. The effects of vitamin D on skeletal muscle function and cellular signaling. J Steroid Biochem Mol Biol. 2011; 125(3):159-68.

112. Girgis CM, Clifton-Bligh RJ, Hamrick MW, Holick MF, Gunton JE. The roles of vitamin D in skeletal muscle: form, function, and metabolism. Endocr Rev. 2013;34(1):33-83.

113. Mihajlovic M, Fedecostante M, Oost MJ, Steenhuis SKP, Lentjes E, MaitimuSmeele I, et al. Role of vitamin D in maintaining renal epithelial barrier function in uremic conditions. Int J Mol Sci. 2017:18(12).

114. Shipton EA, Shipton EE. Vitamin D and pain: vitamin D and its role in the Aetiology and maintenance of chronic pain states and associated comorbidities. Pain Res Treat. 2015;2015:904967.

115. Kalueff AV, Tuohimaa P. Neurosteroid hormone vitamin D and its utility in clinical nutrition. Curr Opin Clin Nutr Metab Care. 2007;10(1):12-9.

116. Borgogni E, Sarchielli E, Sottili M, Santarlasci V, Cosmi L, Gelmini S, et al. Elocalcitol inhibits inflammatory responses in human thyroid cells and $T$ cells. Endocrinology. 2008;149(7):3626-34.

117. Chen S, Sims GP, Chen XX, Gu YY, Chen S, Lipsky PE. Modulatory effects of 1,25-dihydroxyvitamin D3 on human B cell differentiation. J Immunol. 2007;179(3):1634-47.

118. Sochorova K, Budinsky V, Rozkova D, Tobiasova Z, Dusilova-Sulkova S, Spisek R, et al. Paricalcitol (19-nor-1,25-dihydroxyvitamin D2) and calcitriol (1,25-dihydroxyvitamin D3) exert potent immunomodulatory effects on dendritic cells and inhibit induction of antigen-specific T cells. Clin Immunol. 2009;133(1):69-77.

119. Ding C, Wilding JP, Bing C. 1,25-dihydroxyvitamin D3 protects against macrophage-induced activation of NFkappaB and MAPK signalling and chemokine release in human adipocytes. PLoS One. 2013;8(4):e61707.

120. Hübel E, Kiefer T, Weber J, Mettang T, Kuhlmann U. In vivo effect of 1,25dihydroxyvitamin D3 on phagocyte function in hemodialysis patients. Kidney Int. 1973;40(5):927-33.

121. Girasole G, Wang JM, Pedrazzoni M, Pioli G, Balotta C, Passeri M, et al. Augmentation of monocyte chemotaxis by 1 alpha,25-dihydroxyvitamin D3. Stimulation of defective migration of AIDS patients. J Immunol. 1990;145(8):2459-64

122. Weeres MA, Robien $\mathrm{K}$, Ahn YO, Neulen ML, Bergerson R, Miller JS, et al. The effects of 1,25 Dihydroxyvitamin $\mathrm{D}(3)(1,25(\mathrm{OH})(2) \mathrm{D}(3))$ on in vitro human natural killer cell DevelopmentFrom hematopoietic stem cells. J Immunol. 2014;193(7):3456-62.

123. Amrein K, Sourij H, Wagner G, Holl A, Pieber TR, Smolle KH, et al. Short-term effects of high-dose oral vitamin D3 in critically ill vitamin D deficient patients: a randomized, double-blind, placebo-controlled pilot study. Critical care. 2011;15(2):R104

124. Leaf DE, Raed A, Donnino MW, Ginde AA, Waikar SS. Randomized controlled trial of calcitriol in severe sepsis. Am J Respir Crit Care Med. 2014;190(5): 533-41

125. Quraishi SA, De Pascale G, Needleman JS, Nakazawa H, Kaneki M, Bajwa EK et al: Effect of cholecalciferol supplementation on vitamin D status and cathelicidin levels in Sepsis: a randomized, Placebo-Controlled Trial Crit Care Med 2015, 43(9):1928-1937.
126. Nair $P$, Venkatesh $B$, Lee $P$, Kerr $S$, Hoechter DJ, Dimeski G, et al. A randomized study of a single dose of intramuscular cholecalciferol in critically ill adults. Crit Care Med. 2015;43(11):2313-20.

127. Han JE, Jones JL, Tangpricha V, Brown MA, Brown LA, Hao L, et al. High dose vitamin D Administration in Ventilated Intensive Care Unit Patients: a pilot double blind randomized controlled trial. J Clin Trans Endocrin. 2016:4:59-65.

128. Alizadeh N, Khalili H, Mohammadi M, Abdollahi A, Ala S. Effect of vitamin D on stress-induced hyperglycaemia and insulin resistance in critically ill patients. Int J Clin Pract. 2016;70(5):396-405

129. Han JE, Alvarez JA, Jones JL, Tangpricha V, Brown MA, Hao L, et al. Impact of high-dose vitamin D3 on plasma free 25 -hydroxyvitamin D concentrations and antimicrobial peptides in critically ill mechanically ventilated adults. Nutrition. 2017:38:102-8.

\section{Submit your next manuscript to BioMed Central and we will help you at every step:}

- We accept pre-submission inquiries

- Our selector tool helps you to find the most relevant journal

- We provide round the clock customer support

- Convenient online submission

- Thorough peer review

- Inclusion in PubMed and all major indexing services

- Maximum visibility for your research

Submit your manuscript at www.biomedcentral.com/submit 